\title{
Eco-physiological Responses of Carex Schmidtii to Soil Salinization in a Chinese Wetland
}

\author{
Dongjie Zhangi,2, Qing Qi ${ }^{1,2}$, Xuehong Wang ${ }^{1}$, Shouzheng Tong ${ }^{1 *}$, Yu An ${ }^{1}$ \\ ${ }^{1}$ Northeast Institute of Geography and Agricultural Ecology, Chinese Academy of Sciences, Changchun, China \\ ${ }^{2}$ Graduate University of Chinese Academy of Sciences, Beijing, China
}

Received: 18 July 2018

Accepted: 8 September 2018

\begin{abstract}
Soil salinization, a growing problem in arid and semi-arid areas, significantly influences the ecological dynamics and processes in wetland ecosystems. To fully examine the physiological responses with the aim of wetland protection and management, a laboratory simulation experiment was conducted to study the effects of soil salinization on the growth of C. schmidtii tussocks. Plant height and leaf traits, as well as physiological characteristics, were analyzed to explore the responses of $C$. schmidtii to soil salinization. Results showed that the highest value of electrical conductivity (EC) $(4.71 \mathrm{mS} / \mathrm{cm})$ recorded in $4000 \mathrm{mg} / \mathrm{L}$ treatment was 3.04 times greater than the lowest value $(1.55 \mathrm{mS} / \mathrm{cm})$ recorded in $0 \mathrm{mg} / \mathrm{L}$ treatment. It was well demonstrated that plant height under the $1000 \mathrm{mg} / \mathrm{L}$ treatment was $57.6 \%$ greater than that obtained under the $4000 \mathrm{mg} / \mathrm{L}$ treatment. Additionally, the growth of plants under the $4000 \mathrm{mg} / \mathrm{L}$ treatment achieved significantly higher length and the ratio of leaf withering (by 13.76 and 16.42 times, respectively), compared with those obtained under $0 \mathrm{mg} / \mathrm{L}$ treatment. 0 and $1000 \mathrm{mg} / \mathrm{L}$ treatments were found to greatly increase chlorophyll content and decrease malondialdehyde. Hence, slight salinization will stimulate the responses of $C$. schmidtii to environmental fluctuation, but the persistent serious salinization can inhibit the growth and physiology of C. schmidtii. The optimum ecological threshold of salinity for the growth of $C$. schmidtii was in the range $0 \sim 1000$ $\mathrm{mg} / \mathrm{L}$. Results help in understanding the responses of C. schmidtii tussocks to soil salinization, and suggest the vital significance of preventing salinization in the Momoge Wetlands of northeastern China.
\end{abstract}

Keywords: physiological response, soil salinization, Carex schmidtii, Momoge Wetland, wetland management

\section{Introduction}

Soil salinization due to climate change and anthropogenic modification of the hydrological cycle is a growing problem in arid and semi-arid areas [1-2].

*e-mail: tongshouzheng@neigae.ac.cn
Soil salinization increases the environmental variability and results in the structural and functional loss of wetland ecosystem [3-5]. In general, salinization alters the fundamental physicochemical properties of soil and the biogeochemical cycling of nutrient elements, and then affects the growth of wetland vegetation [6]. Additionally, the physiological stress due to soil salinization will induce the large shifts in wetland- 
dominant species and their associated ecosystem functions [7]. Therefore, understanding the responses of wetland plants to soil salinization is important for the protection and restoration of wetlands in arid and semiarid areas.

Momoge National Nature Reserve (MNNR), located in a semi-arid and soda-salinized region of western Sonnen Plain in China, is an internationally important wetland and a vital resting site for the Siberian Crane (Grus leucogeranus) [8-9]. At the same time, this nature reserve also plays an important role in preventing the saline-alkaline desertification of western Sonnen Plain [10]. However, soil salinization due to drought and irrigation has resulted in degradation of wetlands, threatening the persistence of rare bird habitat.

C. schmidtii, a native, tussock-forming species, is wildly distributed in the riparian wetland along the downstream of the Nenjiang River in the MNNR [11]. This species has abundant root systems and a strong accumulation ability, and it is able to support a rich biodiversity [12]. The sponge network structure (hummock) formed by root and peat provides favorable conditions for water conservation and sewage purification in tussock sedge wetlands [13]. Simultaneously, the microtopography created by hummocks not only increases the surface area to support plants being free from inundation, but also expands the living space range of plants to obtain the resources of sunlight, water and nutrients [14]. However, soil salinization of tussock wetland becomes increasingly serious and has resulted in the dying-off of C. schmidtii tussocks. Although previous studies have focused on the effects of water depth and flooding-drought conditions on the growth of C. schmidtii [12-13], few studies have explained how the physiology of $C$. schmidtii responds to soil salinization.

In this study, we conducted a greenhouse experiment to examine plant height, leaf functional traits (leaf area, length, width, shape, the length of withered leaves, the ratio of withered leaf, leaf mass, dry matter content and specific leaf area) and physiological characteristics (chlorophyll and malondialdehyde) of $C$. schmidtii. The purposes were to (1) explore the growth and physiological responses of C. schmidtii to soil salinization, and (2) elucidate the optimum ecological threshold of salinity for the growth of C. schmidtii. Results help in understanding the significance of preventing soil salinization of wetland in an arid and semi-arid region, and provide theoretical support for the protection and management for the tussock wetlands in the MNNR.

\section{Materials and Methods}

\section{Plant Cultivation}

C. schmidtii tussocks (the hummock being above the soil surface) and soil samples from the $0-10 \mathrm{~cm}$ soil layer were collected in November 2016 from the riparian wetland along the downstream of the Nenjiang River $\left(45^{\circ} 53^{\prime} 51.97^{\prime \prime} \mathrm{N}, 123^{\circ} 55^{\prime} 58.57^{\prime \prime} \mathrm{E}\right)$, which was located in the MNNR of northeastern China. Tussocks and soil were taken to a greenhouse at the Northeast Institute of Geography and Agroecology, Chinese Academy of Sciences. We removed the aboveground biomass of tussocks and cut the hummocks into uniform pieces (20 $\mathrm{cm}$ in height and $15 \mathrm{~cm}$ in diameter). These small hummocks were then individually planted in plastic buckets $(35 \mathrm{~cm}$ in height and $30 \mathrm{~cm}$ in diameter). Each bucket was filled with $12 \mathrm{~kg}$ soil to keep a small hummock half in soil and half above it. The soil type used in the study belongs to meadow bog soil with $\mathrm{pH}$ of 7.34, electrical conductivity of $140.50 \mathrm{mS} / \mathrm{m}$, organic carbon content of $33.67 \%$, total nitrogen content of $4.27 \mathrm{~g} / \mathrm{kg}$, total phosphorus content of $0.52 \mathrm{~g} / \mathrm{kg}$, and a carbon isotope $\left(\delta^{13} \mathrm{C}\right)$ of $-27.39 \%$, respectively. The hummock samples (36 in total) were randomly positioned in the greenhouse and repositioned every week. During the experimental period (50 days), tussocks were irrigated with tap water $(1$ liter). The water capacity was about $65 \%$ after irrigation. The temperature of the greenhouse ranged from $23^{\circ} \mathrm{C}$ to $32^{\circ} \mathrm{C}$.

\section{Experiment Design and Laboratory Analyses}

The experiment was conducted on the fifth day after the rhizomes sprouting of $C$. schmidtii. In order to stimulate soil salinization, two liters of the solutions containing $0 \mathrm{mg} / \mathrm{L}, 1000 \mathrm{mg} / \mathrm{L}, 3000 \mathrm{mg} / \mathrm{L}$ and 4000 $\mathrm{mg} / \mathrm{L}$ salinity, which were prepared by $\mathrm{NaCl}$ and $\mathrm{NaHCO}_{3}$ at a ratio of 2:1 and were watered into the planting tussocks, respectively. Each treatment was replicated nine times and lasted 50 days. In the following days, $500 \mathrm{ml}$ tap water was irrigated to all treatments on the $15^{\text {th }}$ and $25^{\text {th }}$ days.

The height of C. schmidtii was measured every six days by a meter rule. At the end of the experiment, leaf morphology of the second leaf, including leaf area, length and width, were determined using a leaf area meter (Yaxin-1242, China). Leaf shape was expressed by the ratio of length to width. We also measured the length of withered leaf (LWL) to calculate the ratio of withered leaf (RWL, the ratio of withered leaf length to leaf length). The plant and the second leaves were harvested to obtain fresh and dry masses. Dry matter content and specific leaf area were used to indicate blade function. Part of fresh leaf samples was used to determine chlorophyll a, chlorophyll b [15] and malondialdehyde (MDA) contents [16]. Fresh leaves $(0.2 \mathrm{~g})$ were soaked in $10 \mathrm{~mL}$ of ethanol-acetone (1:1) for two days in the dark and then centrifuged at $2000 \mathrm{rpm}$ for $15 \mathrm{~min}$. Absorbance of the supernatant was measured at 663 and $645 \mathrm{~nm}$, with an ultraviolet spectrophotometer (Shimadzu UV-2550, China). MDA was measured with thiobarbituric acid to estimate lipid peroxidation. Soil electrical conductivity (EC) 
was determined by a soil moisture sensor (HH2 W.E.T Sensor, Cambridge, UK) every week.

\section{Statistical Analysis}

Data analyses were performed using SPSS 20.0 and Origin 9.2. One-way analysis of variance (ANOVA) was employed to test the effect of salinization on the growth and physiology of $C$. schmidtii. Differences were compared by Duncan's test and different letters indicated significant differences at the 0.05 significance level.

\section{Results and Discussion}

\section{Effect of Soda Salinity on Soil EC in C. schmidtii Tussock Wetland}

As shown in Fig. 1, soil EC significantly increased with increasing salinity concentration from the initiation time of the experiment $(\mathrm{F}>17, p<0.01)$. The soil EC values of $0 \mathrm{mg} / \mathrm{L}$ treatment ranged from $1.35 \mathrm{mS} / \mathrm{cm}$ to $1.64 \mathrm{mS} / \mathrm{cm}$, this being lower than that of other treatments. Additionally, a significant decrease of EC values from the tenth day was observed under $3000 \mathrm{mg} / \mathrm{L}$ and $4000 \mathrm{mg} / \mathrm{L}$ treatments. At the end of the experiment, the highest EC value $(4.71 \mathrm{mS} / \mathrm{cm})$ was recorded in $4000 \mathrm{mg} / \mathrm{L}$ treatment, this being 3.04 times greater than the lowest value recorded in $0 \mathrm{mg} / \mathrm{L}$ treatment. Salinization negatively affects the physicochemical nature of soil, especially the structural stability of soil [17-18]. In addition, soil hydraulic conductivity sharply decreases after irrigation with saline-sodic water, this leading to aggregate slaking and then inhibiting the soil nutrient cycle [19-20]. Zhou et al. (2017) found that soil salinization increased plant nitrogen $(\mathrm{N})$ content and soil total $\mathrm{N}$ content, but decreased soil $\mathrm{NO}_{3}$ and microbial biomass $\mathrm{N}$ [21]. Thus, preventing soil salinization has become

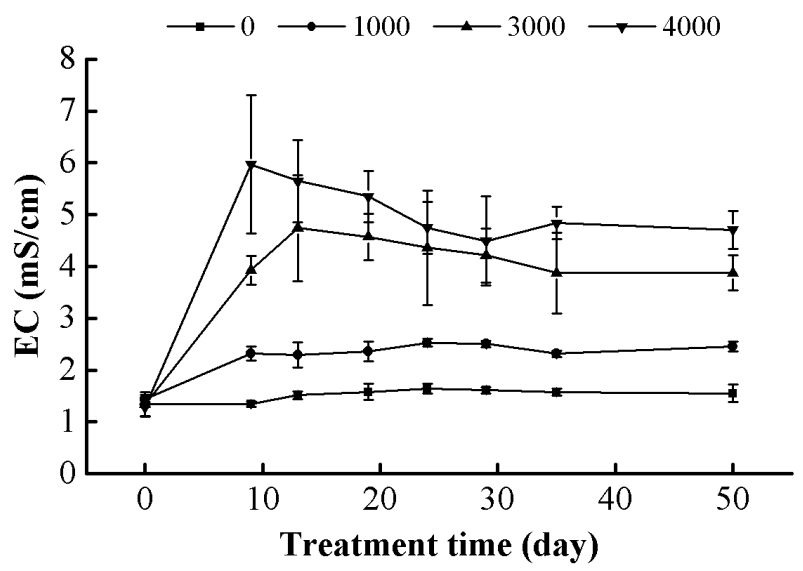

Fig. 1. Variations of soil electrical conductivity (EC) over time $($ mean $\pm \mathrm{SD}, \mathrm{n}=9$ ). much more important for the protecting wetlands in arid and semi-arid areas.

\section{Effects of Soil Salinization on the Growth of C. schmidtii \\ Effects of Soil Salinization on the Height of C. schmidtii}

At the end of the experiment, Significant differences in the height of $C$. schmidtii was identified among the treatments ( $F=15.064, p<0.01$; Fig. 2$)$. The height of $C$. schmidtii rapidly increased first, and then reached a stable state in $0 \mathrm{mg} / \mathrm{L}$ and $1000 \mathrm{mg} / \mathrm{L}$ treatments, while that significantly decreased in $3000 \mathrm{mg} / \mathrm{L}$ and $4000 \mathrm{mg} / \mathrm{L}$ treatments from the $28^{\text {th }}$ day. The height varied from $24.9 \mathrm{~cm}$ to $39.2 \mathrm{~cm}$, peaking in the $1000 \mathrm{mg} / \mathrm{L}$ treatment, which had a value $57.59 \%$ higher than the lowest value recorded in the $4000 \mathrm{mg} / \mathrm{L}$ treatment. Soil salinization affects the growth of C. schmidtii by inhibiting the growth rate of plants.

Salinity is common in abiotic factors influencing the growth and development of wetland plants [18]. However, excessive salinity caused soil salinization and then inhibited the growth of wetland plants. The most visual injury of excessive salinity on the C. schmidii was plant dwarf, which was closely related to the growth rate of plants. According to Fig. 2, the growth rate of plant height in $3000 \mathrm{mg} / \mathrm{L}$ and $4000 \mathrm{mg} / \mathrm{L}$ treatments turned to a negative value from the $28^{\text {th }}$ day, and the negative effects of soil salinization on the growth of C. schmidtii has become serious over time. This was consistent with other studies that found that growth rate and biomass will be reduced when the plants are faced with high saline alkali stress [23-25]. The salinity threshold of some vegetable crops ranged from about 1 to $2.5 \mathrm{mS} / \mathrm{cm}$ and the salt tolerance deceased when the plants were irrigated with saline water [26]. Soil salinization induced by high concentration of ions destroys the absorption function of wetland plants by

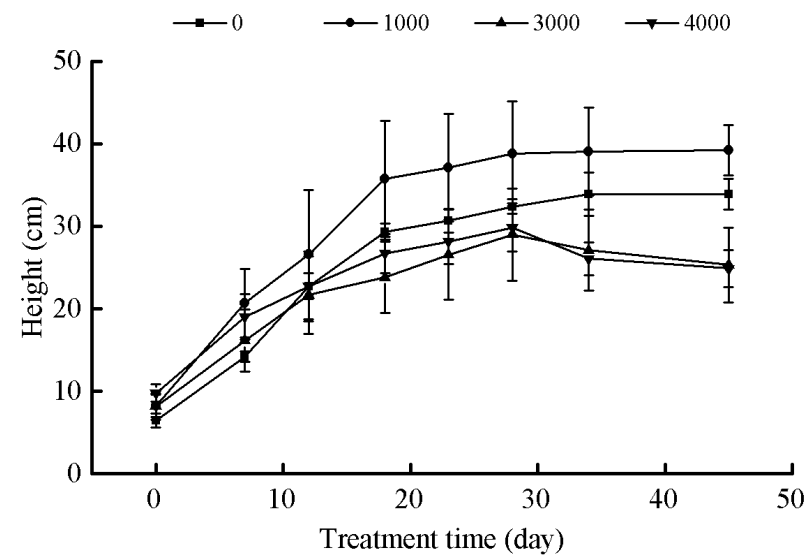

Fig. 2. Variation of the height of C. schmidtii over time $($ mean $\pm \mathrm{SD}, \mathrm{n}=9$ ). 

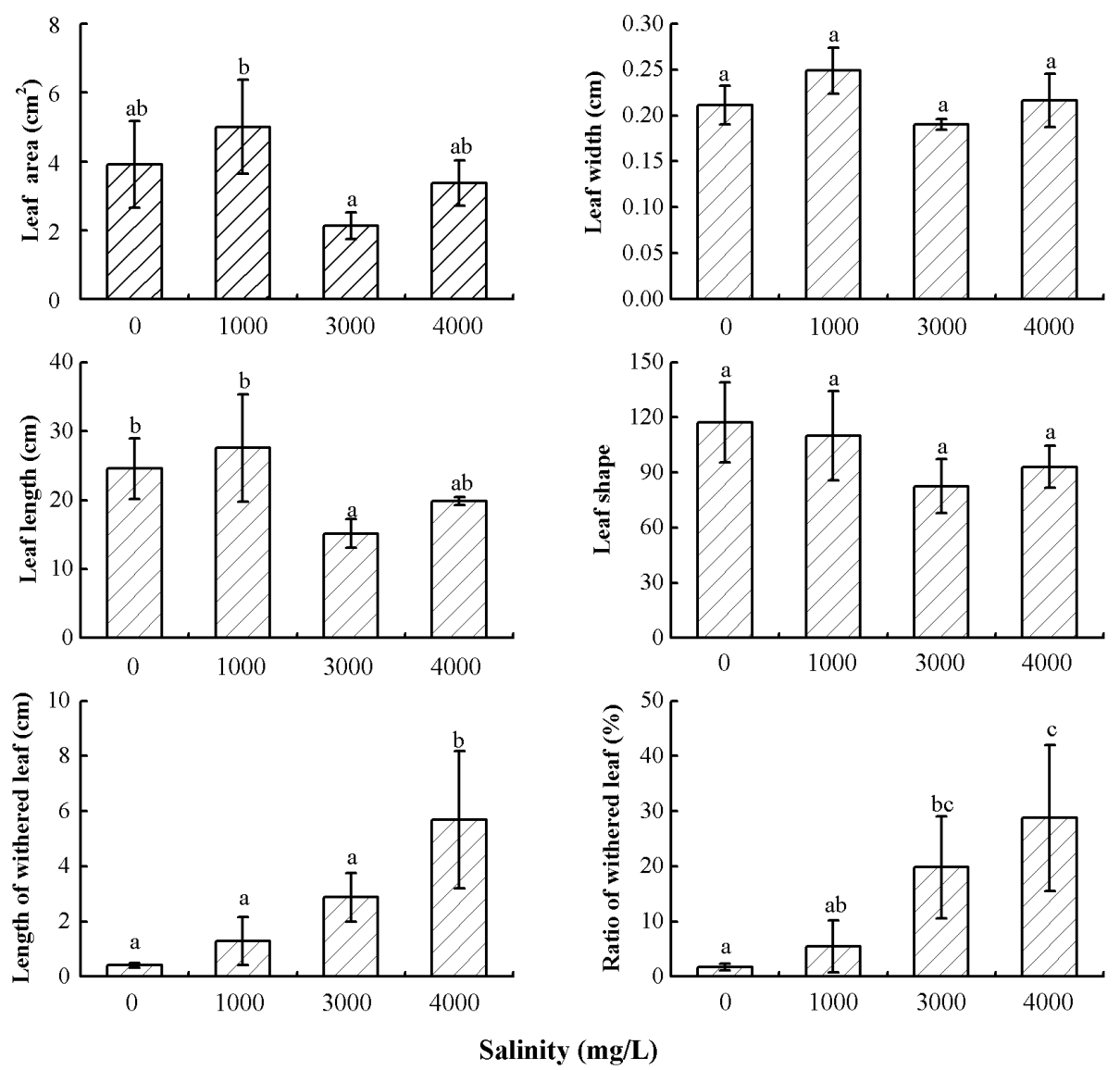

Fig. 3. Effects of soil salinization on leaf morphology of C. schmidtii (mean $\pm \mathrm{SD}, \mathrm{n}=9$ ).

influencing the osmotic pressure of root cells, resulting in nutrient deficiency for the growth of plants [27]. However, some studies have found that low salinealkaline stress promoted the growth of wetland plants through enhancing plant absorption of nutrient elements $[25,28]$.

\section{Effects of Salinization on Leaf Morphology of C. schmidtii}

Soil salinization significantly influenced the leaf area $(\mathrm{F}=4.244, p<0.05)$ and leaf length $(\mathrm{F}=4.200$, $p<0.05$ ) of C. schmidtii (Fig. 3). The maximum of leaf area $(5.00 \mathrm{~cm} 2)$, length $(27.58 \mathrm{~cm})$ and width $(0.25 \mathrm{~cm})$ were all recorded in the $1000 \mathrm{mg} / \mathrm{L}$ treatment. Leaf shape, ranging from 82.57 to $117.26 \mathrm{~mm}$, peaked in the $0 \mathrm{mg} / \mathrm{L}$ treatment. Additionally, there were significant differences in length of withered leaves $(\mathrm{F}=8.271$, $p<0.01)$ and the ratio of withered leaves $(\mathrm{F}=6.733$, $p<0.05$ ). Length of withered leaf and ratio of withered leaf increased with increasing salinity, and reached a peak value in $4000 \mathrm{mg} / \mathrm{L}$. It was noted that the $1000 \mathrm{mg} / \mathrm{L}$ treatment also led to the withered leaf of C. schmidtii.

Plant leaves, as important organs for photosynthesis, are sensitive to environmental fluctuations. In general, plants adapt to environmental fluctuations by changing leaf morphological and physiological traits [29]. For
C. schmidtii, soil salinization reduced leaf morphology, both with respect to leaf area for photosynthesis and leaf shape for dimension. This was related to Pan et al., who found that salinity had a negative effect on leaf area and the relative growth rate [30]. Additionally, the length of withered leaves and the ratio of withered leaves indicated that salinization exerted much injury to leaf morphology, affecting elongation and expansion of leaves. Excessive salinity affected the morphological and physiological processes, including plant growth and water and nutrient uptake [31].

\section{Plant Mass and Leaf Mass of C. schmidtii}

Table 1 shows no significant differences in plant mass and leaf mass of $C$. schmidtii as identified among treatments. The highest values of plant mass, leaf mass and dry matter content were all observed in $1000 \mathrm{mg} / \mathrm{L}$ treatment, while the lowest of those were found in the $3000 \mathrm{mg} / \mathrm{L}$ treatment. Specific leaf area, ranging from 14.57 to $17.30 \mathrm{~m}^{2} / \mathrm{kg}$, peaked in the $0 \mathrm{mg} / \mathrm{L}$ treatment, which had a value $20.48 \%$ higher than that recorded in the $3000 \mathrm{mg} / \mathrm{L}$ treatment.

Specific leaf area and dry matter content are vital proxies for the amount of light absorbed and the biomass stored in leaves [32]. High specific leaf area and mass represents a rapid production of biomass. Hayes et al. (2017) found specific leaf area and leaf 
Table 1. Effects of salinization on plant mass and leaf mass of $C$. schmidtii (mean $\pm \mathrm{SD}, \mathrm{n}=9$ ).

\begin{tabular}{|c|c|c|c|c|c|c|c|}
\hline \multirow{2}{*}{$\begin{array}{c}\text { Salinity } \\
(\mathrm{mg} / \mathrm{L})\end{array}$} & $\begin{array}{c}\text { Fresh mass } \\
\text { per plant }(\mathrm{g})\end{array}$ & $\begin{array}{c}\text { Dry mass } \\
\text { per plant }(\mathrm{g})\end{array}$ & $\begin{array}{c}\text { Dry matter } \\
\text { content } \\
\text { per plant }(\mathrm{g} / \mathrm{g})\end{array}$ & $\begin{array}{c}\text { Fresh mass } \\
\text { per leaf }(\mathrm{g})\end{array}$ & $\begin{array}{c}\text { Dry mass } \\
\text { per leaf }(\mathrm{g})\end{array}$ & $\begin{array}{c}\text { Dry matter } \\
\text { content } \\
\text { per leaf }(\mathrm{g} / \mathrm{g})\end{array}$ & $\begin{array}{c}\text { Specific leaf } \\
\text { area } \\
\left(\mathrm{m}^{2} / \mathrm{kg}\right)\end{array}$ \\
\hline 0 & $0.2579 \pm 0.0318$ & $0.0759 \pm 0.0139$ & $0.2931 \pm 0.0166$ & $0.0703 \pm 0.0150$ & $0.0227 \pm 0.0048$ & $0.3261 \pm 0.0324$ & $17.3101 \pm 2.7614$ \\
\hline 1000 & $0.2989 \pm 0.0604$ & $0.0931 \pm 0.0356$ & $0.3045 \pm 0.0527$ & $0.0984 \pm 0.0331$ & $0.0355 \pm 0.0169$ & $0.3498 \pm 0.0529$ & $15.3678 \pm 4.1004$ \\
\hline 3000 & $0.1946 \pm 0.0304$ & $0.0528 \pm 0.0069$ & $0.2745 \pm 0.0156$ & $0.0518 \pm 0.0056$ & $0.0149 \pm 0.0016$ & $0.2868 \pm 0.0015$ & $14.5712 \pm 1.6054$ \\
\hline 4000 & $0.2265 \pm 0.0857$ & $0.0650 \pm 0.0253$ & $0.2855 \pm 0.0178$ & $0.0729 \pm 0.0185$ & $0.0221 \pm 0.0057$ & $0.3022 \pm 0.0071$ & $15.7647 \pm 2.3284$ \\
\hline
\end{tabular}

mass ratio of plans increased when they were faced with environmental press [33]. However, soil salinization due to high saline-alkali press contributed to a moderate SLA and a low dry mass content. The lowest specific leaf area and dry matter content were recorded in $3000 \mathrm{mg} / \mathrm{L}$ treatment, indicating a conservation of nutrients in plants. Conversely, $0 \mathrm{mg} / \mathrm{L}$ and $1000 \mathrm{mg} / \mathrm{L}$ treatments helped in promising the SLA for photosynthesis. Increasing salinity press negatively affected leaf area and dry weight accumulation and then decreased total yield [34].

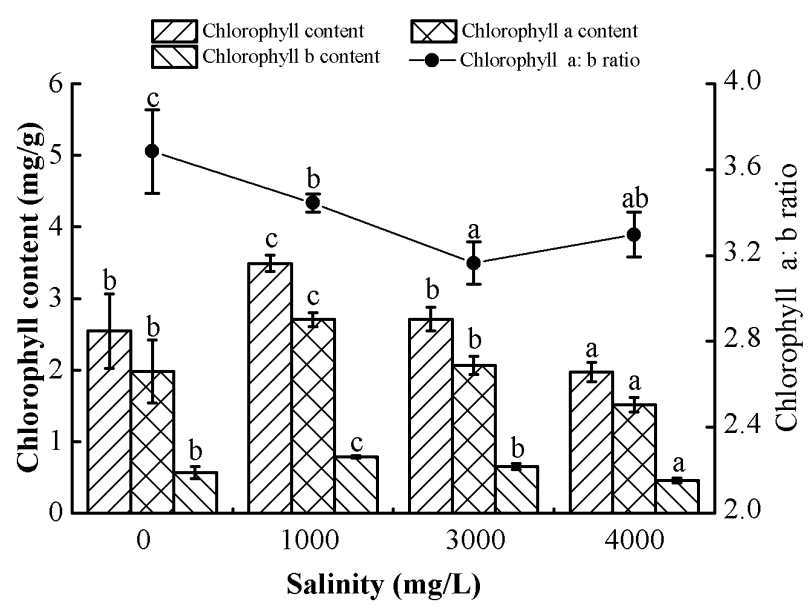

Fig. 4. Effects of soil salinization on chlorophyll content of $C$. schmidtii (mean $\pm \mathrm{SD}, \mathrm{n}=9$ ).

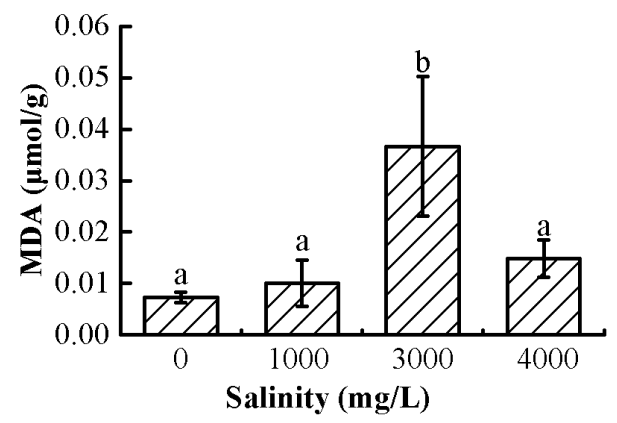

Fig. 5. Effects of soil salinization on malondialdehyde (MDA) content of C. schmidtii (mean $\pm \mathrm{SD}, \mathrm{n}=9$ ).

\section{Physiological Responses of C. schmidtii to Salinization}

As shown in Figs 4 and 5, significant differences in chlorophyll $(\mathrm{F}>9.92, \mathrm{p}<0.01)$ and MDA content $(\mathrm{F}=9.76, p<0.01)$ were found among the treatments. The highest chlorophyll content was recorded in $1000 \mathrm{mg} / \mathrm{L}$ treatment $(3.49 \mathrm{mg} / \mathrm{g})$, and the lowest was recorded in $4000 \mathrm{mg} / \mathrm{L}$ treatment $(1.97 \mathrm{mg} / \mathrm{g})$. Moreover, chlorophyll a:b ratio decreased with increasing salinealkali press. MDA content in $3000 \mathrm{mg} / \mathrm{L}$ treatment was $0.04 \mu \mathrm{mol} / \mathrm{g}$, being 4.99 times greater than the lowest value recorded in $0 \mathrm{mg} / \mathrm{L}$ treatment. Soil salinization decreased the photosynthetic pigments. This was consistent with Zhang et al. (2014), who found that Scirpus planiculmis seedlings had low chlorophyll content when the salinity exceeded $3000 \mathrm{mg} / \mathrm{L}$ [9]. Salinity affected photosystem II efficiency by reducing leaf area and chlorophyll content [35]. Compared to the $3000 \mathrm{mg} / \mathrm{L}$ treatment, MDA has a decrease in $4000 \mathrm{mg} / \mathrm{L}$ treatment. Previous studies also found that the overall inhibition of plant metabolism can decrease MDA in plants.

\section{Conclusions}

Soil salinization negatively affects the growth and physiological traits of C. schmidtii. Soil EC significantly increased with increasing salinity concentration from the initiation time of the experiment. Soil salinization seriously reduced plant height, leaf area and length, and also led to significant leaf withering. However, slight salinization $(1000 \mathrm{mg} / \mathrm{L})$ improved the plant mass and leaf mass with a high biomass accumulation. Additionally, chlorophyll and MDA concentration indicated that 0 and $1000 \mathrm{mg} / \mathrm{L}$ treatment exerted less injury to the leaves of C. schmidtii. Therefore, the optimum ecological threshold of salinity for the growth of $C$. schmidtii was in the range $0 \sim 1000 \mathrm{mg} / \mathrm{L}$. However, serious soil salinization inhibited the growth of $C$. schmidtii and resulted in the degradation of tussock wetlands. Preventing soil salinization will be an efficient method for protecting and restoring tussock sedge wetlands in the MNNR. 


\section{Acknowledgements}

This research was supported by the National Key R\&D Program of China (2016YFC0500403) and the National Natural Science Foundation of China (41871101)

\section{Conflict of Interest}

The authors have not declared any conflict of interest.

\section{References}

1. ALLBED A., KUMAR L. Soil salinity mapping and monitoring in arid and semi-arid regions using remote sensing technology: a review. Advances in remote sensing, 2 (04), 373, 2013.

2. LI J., PU L., HAN M., ZHU M., ZHANG R.S., XIANG Y.Z. Soil salinization research in China: advances and prospects. Journal of Geographical Sciences, 24 (5), 943, 2014.

3. HERBERT E.R., BOON P., BURGIN A.J., NEUBAUER S.C., FRANKLIN R.B., ARDON M., HOPFENSPERGER K.N., LAMERS L.P., GELL P. A global perspective on wetland salinization: ecological consequences of a growing threat to freshwater wetlands. Ecosphere, 6 (10), $1,2015$.

4. WEN B., LIU X., LI X., YANG F.Y., LI X.Y. Restoration and rational use of degraded saline reed wetlands: a case study in western Songnen Plain, China. Chinese Geographical Science, 22 (2), 167, 2012.

5. ZHAO Q., BAI J., LU Q., ZHANG G.L. Effects of salinity on dynamics of soil carbon in degraded coastal wetlands: Implications on wetland restoration. Physics and Chemistry of the Earth, 97, 12, 2017.

6. CHAMBERS L.G., OSBORNE T.Z., REDDY K.R. Effect of salinity-altering pulsing events on soil organic carbon loss along an intertidal wetland gradient: a laboratory experiment. Biogeochemistry, 115 (1-3), 363, 2013.

7. WANG X., YU J., ZHOU D., DONG H.F., LI Y.Z., LIN Q.X., GUAN B., WANG Y.L. Vegetative ecological characteristics of restored reed (Phragmites australis) wetlands in the Yellow River Delta, China. Environmental management, 49 (2), 325, 2012.

8. JIANG H., WEN Y., ZOU L., WANG Z.Q., HE C.G., ZOU C.L. The effects of a wetland restoration project on the Siberian crane (Grus leucogeranus) population and stopover habitat in Momoge National Nature Reserve, China. Ecological Engineering, 96, 170, 2016.

9. ZHANG L., ZHANG G., LI H., SUN G.Z. Ecophysiological responses of Scirpus planiculmis to different water-salt conditions in Momoge wetland. Polish Journal of Environmental Studies, 23 (5), 1813, 2014.

10. YU X., DING S., ZOU Y., XUE Z.S., LV X G., WANG G.P. Review of rapid transformation of floodplain wetlands in northeast China: Roles of human development and global environmental change. Chinese Geographical Science, 28, 4, 654, 2018.

11. WANG Y., FENG J., LIN Q., LIN Q.X., LV X.G., WANG X.Y., WANG G.P. Effects of crude oil contamination on soil physical and chemical properties in Momoge wetland of China. Chinese Geographical Science 23, 708, 2013.

12. YAN H., LIU R.Q., LIU Z.N., WANG X., LUO W.B., SHENG L.X. Growth and physiological responses to water depths in Carex schmidtii Meinsh. PloS one, 10 (5), 2015.

13. ZHANG D.J., QI Q., TONG S.Z., ZHANG Z.S., WANG X.H., AN Y., PAN Y.W. Effect of alternative dry-wet shiftinig on eco-physiological characteristics of Carex schmidtii tussocks. Chinese Journal of Ecology, 37 (1), 43, 2018 [In Chinese].

14. WANG M., WANG G., WANG S., JIANG M. Structure and Richness of Carex meyeriana tussocks in peatlands of Northeastern China. Wetlands, 38 (1), 15, 2017.

15. JIA X.Y., TIAN Z.J., QIN L., ZHANG L.L., ZOU Y.C., JIANG M., LYU X.G. Iron regulation of wetland vegetation performance through synchronous effects on phosphorus acquisition efficiency.Chinese Geographical Science, 28 (02), 337, 2018.

16. SCHMEDES A., HOLMER G. A new thiobarbituric acid (TBA) method for determing free malondialdehyde (MDA) and hydroperoxides selectively as a measure of lirid-peroxidation.. Journal of the American Oil Chemists Society, 66, 813, 1989.

17. DOU C.Y., KANG Y.H., WAN S.Q., HU W. Soil salinity changes under cropping with Lycium barbarum L. and irrigation with saline-sodic water. Pedosphere, 21, 539, 2011.

18. LIU M., YANG J., LI X., LIU G.M., YU M., WANG J. Distribution and dynamics of soil water and salt under different drip irrigation regimes in northwest China. Irrigation Science, 31, 675, 2013.

19. MANDAL U.K., BHARDWAJ A.K., WARRINGTON D.N., GOLDSTEIN D., BAR TAL A., LEVY C.L. Changes in soil hydraulic conductivity, runoff, and soil loss due to irrigation with different types of saline-sodic water. Geoderma, 144, 509, 2008.

20. LIU X., RUECKER A., SONG B., XING J., WILLIAM H.C., ALEX T.C. Effects of salinity and wet-dry treatments on $\mathrm{C}$ and $\mathrm{N}$ dynamics in coastal-forested wetland soils: Implications of sea level rise. Soil Biology and Biochemistry, 112, 56, 2017.

21. ZHOU M.H., BUTTERBACH-BAHL K., VEREECKEN H., NICOLAS B. A meta-analysis of soil salinization effects on nitrogen pools, cycles and fluxes in coastal ecosystems. Global change biology, 23, 3, 1338, 2017.

22. GONZALEZ-ALCARAZ M.N., JIMENEZ-CARCELES F.J., ÁlVAREZ Y., ÁLVAREZ-ROGEL J. Gradients of soil salinity and moisture, and plant distribution in a Mediterranean semiarid saline watershed: a model of soilplant relationships for contributing to the management. Catena, 115, 150, 2014.

23. LI X., KANG Y., WAN S., CHEN X.L., LIU S.P., XU J.C. Response of a salt-sensitive plant to processes of soil reclamation in two saline-sodic, coastal soils using drip irrigation with saline water. Agricultural Water Management, 164, 223, 2016.

24. VISSER J.M., PETERSON J.K. The effects of flooding duration and salinity on three common upper estuary plants. Wetlands, 35, 625, 2015.

25. LIU Y., DING Z., BACHOFEN C., LOU Y.J., JING M., TANG X.G., LV X.G., NINA B. The effect of salinealkaline and water stresses on water use efficiency and standing biomass of Phragmites australis and Bolboschoenus planiculmis. Science of the Total Environment, 644, 207, 2018. 
26. MACHADO R.M.A., SERRALHEIRO R.P. Soil salinity: effect on vegetable crop growth. Management practices to prevent and mitigate soil salinization. Horticulturae, 3, 30, 2017.

27. DE SOUZA E.R., GALVAO DOS M.B., VIEIRA DA CUNHA K.P., DO NASCIMENTO C.W.A., RUIZ H.A., LINSA C.M.T. Biomass, anatomical changes and osmotic potential in Atriplex nummularia L. cultivated in sodic saline soil under water stress. Environmental and Experimental Botany, 82, 20, 2012.

28. LIANG Y., ZHU H., BANUELOS G., YAN B.X., BRIAN S., CHEN X.W., CHEN X. Removal of nutrients in saline wastewater using constructed wetlands: plant species, influent loads and salinity levels as influencing factors. Chemosphere, 187, 52, 2017.

29. GUO C., MA L., YUAN S., WANG R.Z. Morphological, physiological and anatomical traits of plant functional types in temperate grasslands along a large-scale aridity gradient in northeastern China. Scientific Reports, 7, 40900, 2017.

30. PAN Y.W., GU Y.B., TANG Z.H., JIANG M., LV X.G., LOU Y.J. Effects of salinity and nitrogen addition on growth and biomass allocation of Phragmites australias seedlings in saline-alkali wetland. Soils and Crops, 7, (2), 257, 2018 [In Chinese].
31. AKBARIMOGHADDAM H., GALAVI M., GHANBARI A., PANJEHKEH N. Salinity effects on seed germination and seedling growth of bread wheat cultivars. Trakia journal of Sciences, 9 (1), 43, 2011.

32. DAWSON S.K., WARTON D.I., KINGSFORD R.T., BERNEY P., KEITH D.A., CATFORD J.A. Plant traits of propagule banks and standing vegetation reveal flooding alleviates impacts of agriculture on wetland restoration. Journal of Applied Ecology, 54, 1907, 2017.

33. HAYES M.A., JESSE A., TABET B., REEF R., KEUSKAMP J.A., LOVELOCK C.E. The contrasting effects of nutrient enrichment on growth, biomass allocation and decomposition of plant tissue in coastal wetlands. Plant and Soil, 416, 193, 2017.

34. DE PASCALE S., MAGGIO A., ORSINI F., STANGHELLINIC C., HEUVELINK E. Growth response and radiation use efficiency in tomato exposed to shortterm and long-term salinized soils. Scientia Horticulturae, 189, 139, 2015.

35. JIANG Q., ROCHE D., MONACO T.A., DURHAM S. Gas exchange, chlorophyll fluorescence parameters and carbon isotope discrimination of 14 barley genetic lines in response to salinity. Field Crops Research, 96, (2-3), 269, 2006. 